Article

\title{
Dynamics of Glyphosate Resistance in Lolium perenne: Pollen-Mediated Gene Flow under Field Conditions in Argentina
}

\author{
Marcos Yanniccari ${ }^{1, *}$, Carolina Istilart ${ }^{2}$, Daniel Giménez ${ }^{3}$ and Ana Castro ${ }^{4}$ \\ 1 National Scientific and Technical Research Council-CONICET, Laboratorio de Biotecnología y Genética \\ Vegetal, Chacra Experimental Integrada Barrow (MAIBA-INTA), RN 3 km 487, \\ Tres Arroyos CP 7500, Argentina \\ 2 Chacra Experimental Integrada Barrow (MAIBA-INTA), RN 3 km 487, Tres Arroyos CP 7500, Argentina; \\ istilart.carolina@inta.gob.ar \\ 3 College of Agronomy and Forestry, Universidad Nacional de La Plata, 60 y 119, La Plata CP 1900, Argentina; \\ danielogimenez@gmail.com \\ 4 National Scientific and Technical Research Council-CONICET, College of Agronomy and Forestry, \\ Universidad Nacional de La Plata, 60 y 119, La Plata CP 1900, Argentina; castro.am@gmail.com \\ * Correspondence: marcosyanniccari@conicet.gov.ar; Tel.: +54-02983-43-1083 (ext. 135)
}

Received: 22 October 2018; Accepted: 23 November 2018; Published: 30 November 2018

\begin{abstract}
The genus Lolium has shown a high tendency to evolve resistance to herbicides. Considering the high level of allogamy of L. perenne and the importance of the wind as an agent for pollen dispersion, the aim of this work was to assess and quantify the effective glyphosate-resistant gene flow by pollen in L. perenne under field conditions. Pollen-mediated gene flow from glyphosate-resistant to -susceptible plants was studied using a donor-receptor design. The results indicate that the effective gene flow reached trap plants distanced $\leq 35 \mathrm{~m}$ downwind from the source of pollen. The progeny of receptor plants growing $0 \mathrm{~m}$ from the pollen donors showed $13 \%$ of individuals with low glyphosate sensitivity. This represents a seven-fold increase in the frequency of glyphosate-resistant individuals found in the progeny of plants isolated during the flowering period (negative control). Similarly, the progenies of plants grown at 15 and $25 \mathrm{~m}$ from the source of glyphosate resistance showed an increase in the frequency of resistant plants by about four- and two-fold, respectively. When the receptor plants were located at $>35 \mathrm{~m}$, no glyphosate-resistant plants were detected in their progenies. Management should aim for prevention or delay of flowering of glyphosate-resistant plants.
\end{abstract}

Keywords: ryegrass; flowering; weed; cross-pollination

\section{Introduction}

The development of herbicide resistance in a weed population is an evolutionary process [1]. Until now, around 500 cases of herbicide-resistant weed populations have been reported [2]. Among these, the genus Lolium has shown high tendency to evolve herbicide resistance, and it includes species of the more troublesome cases of resistance in the world [2-7].

Two requisites are necessary for the evolution of resistance to herbicides in a weed population: the existence of genetic variation for resistance, and the selection pressure imposed by the use of a herbicide [8]. The first condition could be generated by spontaneous mutations [9]; however, gene flow through dispersal of pollen or seed from resistant weed populations can also provide a source of variation for resistance in previously susceptible populations. In fact, gene flow rates are generally higher than mutation rates, thus, the time required to reach a high level of resistance is greatly reduced through gene flow [10]. 
The increased area sown with herbicide-resistant crops has determined that gene flow studies gain special attention [11,12]. Also, after the detection of herbicide-resistant weed populations, the dispersion of resistant genes through pollen and/or seeds has been addressed to predict the evolution of the resistance [13-16].

Although studies of seed dispersal are important for improving knowledge of weed dynamics, gene flow through pollen has been estimated to be 3.5 times greater than flow through seeds in Perennial ryegrass (Lolium perenne L.) [17]. This species is considered an anemophilous and obligated allogamous plant, where a gametophytic system of self-incompatibility based on two multiallelic and independent loci, called $S$ and $Z$, operate to prevent inbreeding [18]. Regarding the high level of allogamy in L. perenne and the importance of the wind as an agent for pollen dispersion, the gene flow through pollen should be considered as the main cause of genetic interchange between herbicide-resistant and -susceptible populations.

Under field conditions, pollen-mediated gene flow was detected in L. rigidum between herbicide-resistant and -susceptible plants spaced at different distances [13-16]. Considering that topographic properties, like different environmental conditions and pollinator variants, affect the pollen-mediated gene flow $[13,16,19]$, these experiments contributed to knowledge about Lolium spp. pollen dispersal and potential cross-pollination in different environments.

The widespread global distribution of Lolium spp. has enabled the evolution of glyphosate resistance in these species [3]. In Argentina, a glyphosate-resistant population of L. perenne $(2 n=14)$ was identified [20], for which a 10.8-fold increase in glyphosate dose was required to achieve a similar control as a susceptible population [20]. The overexpression of the glyphosate target enzyme (EPSPS: 5-enolpyruvylshikimate-3-phosphate synthase) appeared to be the main mechanism of resistance [21]. It was found that this trait is controlled by a single nuclear locus with intermediate dominance [22].

In addition, glyphosate resistance could be inherited not only among L. perenne plants, but also from that species to the hybrid offspring with L. multiflorum [22]. Naturalised populations of Lolium spp. in Argentina are very frequent in plant communities of croplands and grasslands of the Pampas region [23]. In cereal crops from the south of that region, L. multiflorum and L. perenne have shown a constancy of $40 \%$ [24,25] and $20 \%$ of these naturalised populations, consisting of $\geq 10 \%$ of glyphosate-resistant plants [26]. In wheat and barley, yield losses due to Lolium spp. competition were recorded to be about $40 \%-50 \%$ [23].

In this context, glyphosate-resistant gene dispersal via pollen should be considered for assessing the spread of glyphosate resistance, and to design strategies of weed management. The hypothesis is that glyphosate-resistant gene flow via pollen occurs in L. perenne under field conditions of Argentina.

The aim of the current work was to assess and quantify the effective glyphosate-resistant gene flow by pollen (i.e., viable pollen to pollinate a flower) under field conditions, in the south of the Buenos Aires province (Argentina).

\section{Materials and Methods}

\subsection{Plant Material}

In 2009, 100 Lolium perenne plants were harvested from a glyphosate-resistant population located in the south of the Buenos Aires province (Argentina; $38^{\circ} 25^{\prime} \mathrm{S}, 60^{\circ} 58^{\prime} \mathrm{W}$ ). The mechanism of resistance involved, and the inheritance of glyphosate resistance of that population, have been previously studied [20-22]. The collected seeds were sown in a plot of $10 \times 20 \mathrm{~m}$ during March 2011 in the Chacra Experimental Integrada Barrow (INTA-MAIBA; $38^{\circ} 19^{\prime} \mathrm{S}, 60^{\circ} 14^{\prime} \mathrm{W}$ ) as the source of pollen from glyphosate-resistant plants. The planting was carried out after tilling the soil with a disc harrow. An experimental plot seeder, with six rows spaced $0.2 \mathrm{~m}$ from each other and calibrated for a seed rate of $10 \mathrm{~kg} \mathrm{ha}^{-1}$, was used. In similar conditions, seeds of susceptible L. perenne plants from a pasture without a history of glyphosate selection were used as pollen receptors. The susceptible plants were sown in six rows (spaced $0.2 \mathrm{~m}$ from each other) at the contour of the glyphosate-resistant source, 
and a plot of $1.2 \times 90 \mathrm{~m}$ from the source of pollen (Figure 1a). This receptor plot was oriented toward the northeast, taking into account the anemophilous type of pollination of L. perenne, and the dominant winds during the pollination period, according to the CEI Barrow agrometeorological station register (Figure 1b).

Prior to pollination on 12 August 2011, five cages $(0.5 \times 0.5 \times 0.8 \mathrm{~m})$ with double-voile cloth were installed on the parcel of susceptible plants, in order to prevent pollination from the glyphosateresistant source. Cages were located at 10, 30, 50, 70, and $90 \mathrm{~m}$ from the parcel of glyphosate-resistant plants. The cages were removed on 1 December, when the pollination period was over; the isolated plants were labelled, and finally harvested at maturity stage.

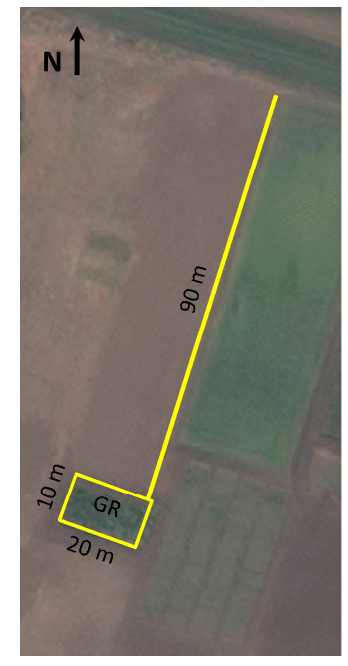

(a)

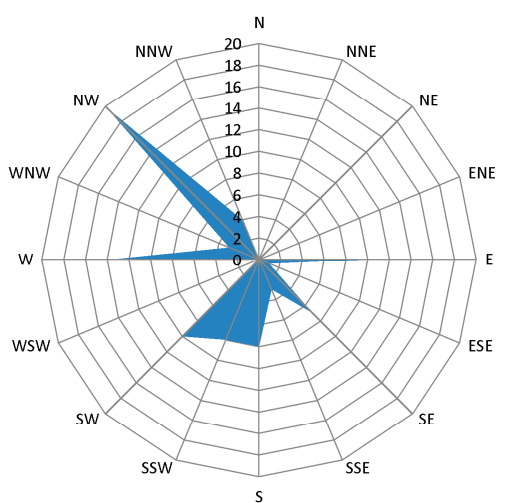

(b)

Figure 1. (a) Satellite image of the pollen-mediated gene flow experiment in Lolium perenne: parcel of glyphosate-resistant plants (GR) as source of pollen, and glyphosate susceptible plants (yellow segments) as pollen receptors; (b) Wind rose showing the frequency distribution (\%) of wind directions at $2 \mathrm{~m}$ above ground level for November (average daily wind direction from 2008 to 2012) in Chacra Experimental Integrada Barrow.

Ten glyphosate-resistant pollen receptor plants located at $0,15,25,35,45,55,65,75$, and $85 \mathrm{~m}$ from the source of pollen were harvested on 27 December (harvest maturity stage). Also, ten glyphosate-resistant plants were harvested from the pollen donor plot at maturity. These seeds were used as positive control for glyphosate resistance, and the seed sample obtained from isolated plants was used as negative control.

\subsection{Glyphosate Sensitivity Evaluations}

\subsubsection{Glyphosate Effects on Plumule Growth}

This bioassay was based on the evaluation of plumule growth of the progenies harvested on receptor plants, when subjected to differing glyphosate concentrations. This experiment was carried out 6 months after harvest maturity when the dormancy period ended.

Previously, 50 seeds from positive and negative control plants were tested in Petri dishes $(9 \mathrm{~cm}$ diameter) containing a sheet of filter paper, and $5 \mathrm{~mL}$ of the following glyphosate (isopropylamine salt of glyphosate, Roundup ${ }^{\circledR}, 360 \mathrm{~g}_{\text {ae L }}{ }^{-1}$, Monsanto Argentina, Buenos Aires, Argentina) solutions: 0, $10,20,40,80,160$, and $320 \mathrm{mg}$ ae $\mathrm{L}^{-1}$ [20]. For each treatment, there were three replicate Petri dishes in a completely randomised design. This experiment was carried out in a growth chamber with $75 \mu \mathrm{mol}$ $\mathrm{m}^{-2} \mathrm{~s}^{-1}$ of photosynthetically active radiation, in a 12:12 h light/darkness regime, and temperatures of $25^{\circ} \mathrm{C} / 15^{\circ} \mathrm{C}$ day/night. After 7 days, the plumule length was measured from the point of attachment 
to the seed to the tip of the coleoptile. Data were used to build dose-response curves with a non-linear log-logistic regression model, as described by Streibig et al. [27]:

$$
y=C+(D-C) /\left(1+\left(x / I_{50}\right)^{b}\right)
$$

where $y$ represents the percentage of response at the herbicide concentration $x ; C$ is the lower asymptote or response at infinitely large herbicide concentration or rate; $D$ is the upper asymptote or mean response when the herbicide concentration or rate is zero; $b$ is the slope of the line at $I_{50}$-the herbicide concentration required to get $50 \%$ of the maximum response. To assess the accuracy of the model, F-test for model significance, residual variance analysis, and coefficient of determination $\left(R^{2}\right)$ were calculated. The glyphosate sensitivity of positive and negative control plants was contrasted through comparing their $I_{50}$ values.

Subsequently, the progenies of pollen receptor plants were evaluated. For this purpose, 50 seeds obtained from the pollen receptor plants of each sample and positive and negative controls were tested in Petri dishes ( $9 \mathrm{~cm}$ diameter) containing a sheet of filter paper and $5 \mathrm{~mL}$ of a glyphosate solution of $45 \mathrm{mg}$ ae $\mathrm{L}^{-1}$ (1.5-fold higher than the $I_{50}$ calculated on the seed germination percentage of negative control). The incubation conditions were the same as described above. After 7 days, the percentage of germinated seeds and plumule length were recorded in the same way. Three replicate Petri dishes were used in a completely randomised design $(n=3)$. The data were then analysed using one-way ANOVAs. Frequency distributions were evaluated by chi-squared tests $(p>0.05)$, and observed frequencies of each sample were compared to expected frequencies (determined in the negative control): the null hypothesis $\mathrm{H}_{0}$ was that the observed frequency distribution for any seed sample tested would have been the same as the expected frequency. When $\mathrm{H}_{0}$ was rejected, class frequencies of the sample were compared to the negative control using two-sample $z$-test $(p<0.05)$.

\subsubsection{Plant Growth under Glyphosate Treatment}

Growth of the progenies obtained at different distances from the source of glyphosate-resistant genes, and from the positive and negative controls, was evaluated under a glyphosate treatment and without herbicide. Seeds were germinated in Petri dishes containing filter paper with distilled water when the dormancy period ended. A germination test was performed in a growth chamber with $75 \mu \mathrm{mol} \mathrm{m} \mathrm{m}^{-2} \mathrm{~s}^{-1}$ of photosynthetically active radiation, in a regime of 12:12 h of light/darkness and temperatures of $25^{\circ} \mathrm{C} / 15^{\circ} \mathrm{C}$ day/night, respectively. After 7 days, each seedling was transferred to a $250 \mathrm{~cm}^{3}$ pot with soil as substrate in a greenhouse. Pots were irrigated to field capacity, according to plant demand. When the plants had at least three tillers, ten plants of each progeny $(n=10)$ were treated with glyphosate using a laboratory belt sprayer calibrated to deliver $200 \mathrm{~L} \mathrm{ha}^{-1}$ at $1000 \mathrm{~g} \mathrm{ae} \mathrm{ha}^{-1}$. The application was carried out at 08:00.

The glyphosate effects on growth were evaluated following Yanniccari et al. [28]. After the glyphosate application, the plants were kept in a greenhouse $\left(25^{\circ} \mathrm{C}\right)$ under sunlight for $3 \mathrm{~h}$ (which is the time necessary for glyphosate translocation in the plant [27]). Later, all tillers of each plant were cut at $2.5 \mathrm{~cm}$ above the neck. At $72 \mathrm{~h}$ post-application, growth was estimated measuring the length of the regrowth above the cut level. The data were then analysed using one-way ANOVA. The differences among mean values were compared with Tukey's HSD test $(p<0.05)$.

\subsubsection{Plant Survival to Glyphosate}

Glyphosate sensitivity of progenies, together with positive and negative controls, was compared after application of differing doses. Ten plants of every progeny were grown in $1 \mathrm{~L}$ pots filled with soil (experimental plot). When the plants had 2-3 tillers, glyphosate was sprayed using a laboratory belt sprayer calibrated to deliver $200 \mathrm{~L} \mathrm{ha}^{-1}$ at 500, 1000 (recommended dose), or $2000 \mathrm{~g}$ ae ha $^{-1}$. Five pots were used as replicates by progeny and by treatment $(n=5)$. At 20 days post-application, plants with severe visual injury (wilting, chlorosis of newly emerged leaves, and general brownish colour) were 
recorded as "controlled plants" (i.e., did not survive). In contrast, plants with green young leaves, and without wilt symptoms, were considered as "survivors". The number of survivor plants was recorded, and data was analysed using a factorial ANOVA, where progeny and dose were the sources of variation. Differences among mean values were compared with Tukey's HSD test $(p<0.05)$.

Experiments to examine glyphosate sensitivity were replicated twice. ANOVAs indicated no significant effects for experimental runs; therefore, the data of both experimental replicates were pooled.

\section{Results and Discussion}

Glyphosate-resistant and -susceptible materials showed flowering synchrony, with the beginning of flowering on 20 and 23 October, respectively. The flowering stage was spread throughout 25 days, and anthesis progressed according to tiller appearance. In the donor plot were counted $576( \pm 57)$ heads $\mathrm{m}^{-2}$ and the receptor plot showed $527( \pm 67)$ heads $\mathrm{m}^{-2}$. During the flowering period, four rain days (cumulative rainfall was $148 \mathrm{~mm}$ ) were registered, and the average wind speed was $12.1 \mathrm{~km} \mathrm{~h}^{-1}$, with the prevailing direction being from south (data from meteorological station from Chacra Experimental Integrada Barrow). Considering that air temperature and relative humidity are the two main environmental factors that affect pollen viability [29], along the pollination period, the average air temperature was $15.0( \pm 6.6){ }^{\circ} \mathrm{C}$, and the relative humidity was $66 \%( \pm 3 \%)$ (data from meteorological station from Chacra Experimental Integrada Barrow) and they would not be detrimental for pollen viability and longevity [16].

\subsection{Glyphosate Effects on Plumule Growth}

Glyphosate sensitivity was significantly different between the progeny of glyphosate-resistant plants harvested from the pollen donor plot (positive control) and the progeny obtained from isolated glyphosate-susceptible plants (negative control) $(p=0.03)$. The plumule growth of progeny of susceptible isolated plants (negative control) showed higher sensitivity to glyphosate than those collected from the positive control, where the half-inhibition concentrations ( $\left.I_{50}\right)$ were 30.5 and $90.7 \mathrm{mg}$ ae $\mathrm{L}^{-1}$, respectively (Figure 2 ).

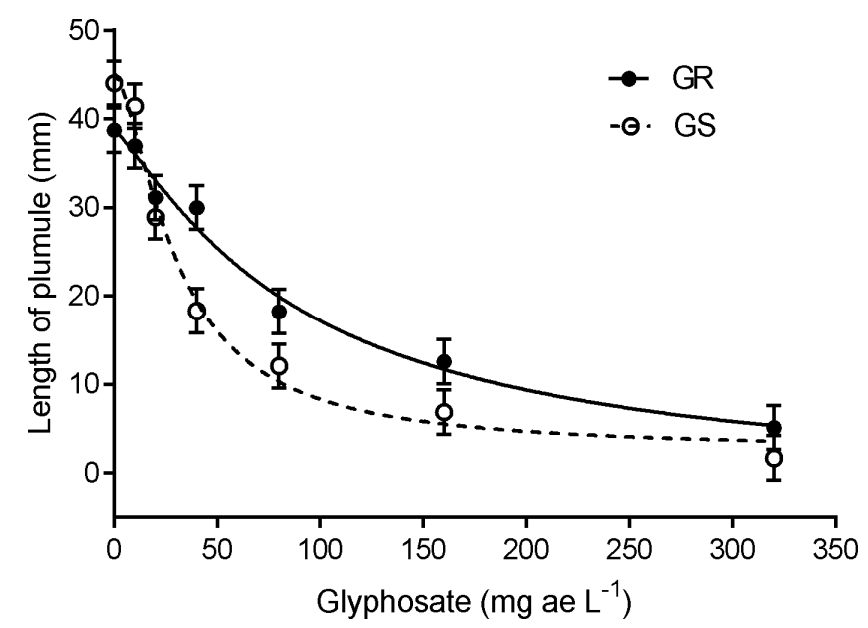

Figure 2. Effects of glyphosate on plumule growth of the progenies of glyphosate-resistant plants (positive control, GR) and glyphosate-susceptible plants (negative control, GS). Symbols indicate mean values, and vertical bars represent \pm 1 standard error. Non-linear regression models are shown by lines $\left(\mathrm{GR}\left(p<0.05\right.\right.$ and $\left.R^{2}=0.98\right): y=-2.0+(38.8-(-2.0)) /\left(1+(x / 90.7)^{1.2}\right)$ and GS $\left(p<0.05\right.$ and $\left.R^{2}=0.98\right)$ : $\left.y=2.5+(45.1-2.5) /\left(1+(x / 30.5)^{1.5}\right)\right)$.

The progeny of pollen receptor plants showed no differences on germination percentage when the seeds were germinated on a glyphosate solution of $45 \mathrm{mg} \mathrm{ae}^{-1}(p=0.75)$. Mean germination was around $52 \%$ to $71.3 \%$ among progenies (data not shown). When the plumule growth was analysed, 
the progenies significantly differed in glyphosate sensitivity, depending on the distance from the receptor plants to the glyphosate-resistant pollen donors $(p<0.001)$.

At this glyphosate concentration, the highest mean plumule length was recorded for the progeny of positive control (GR), while the progeny of negative control (GS) showed a mean plumule length of half of that determined on the progeny of GR (Figures 3 and 4). The progeny obtained from receptor plants located close to glyphosate-resistant pollen donor plants $(0 \mathrm{~m})$ showed no significant differences in plumule growth, compared with positive controls (Figure 3). Mean plumule length was not significantly different to the negative control when the distance between glyphosate-resistant plants and pollen receptors was $\geq 15 \mathrm{~m}$ (Figure 3).

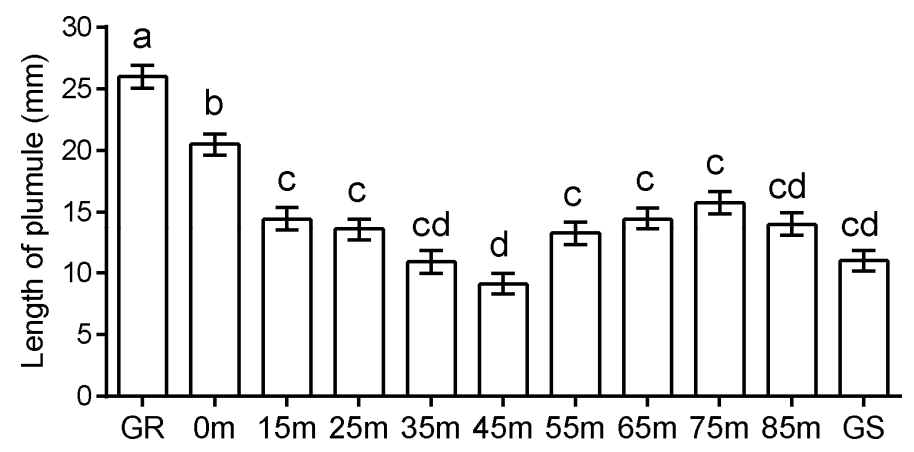

Figure 3. Glyphosate effects on plumule growth of progenies of pollen receptor plants (spaced from 0 to $85 \mathrm{~m}$ from the glyphosate-resistant plants as the source of pollen), glyphosate-resistant plants (GR, positive control), and isolated glyphosate-susceptible plants (GS, negative control). Bars indicate mean values, error bars represent \pm 1 standard error, and bars with the same letters are not significantly different ( $p>0.05$; Tukey's HSD test).

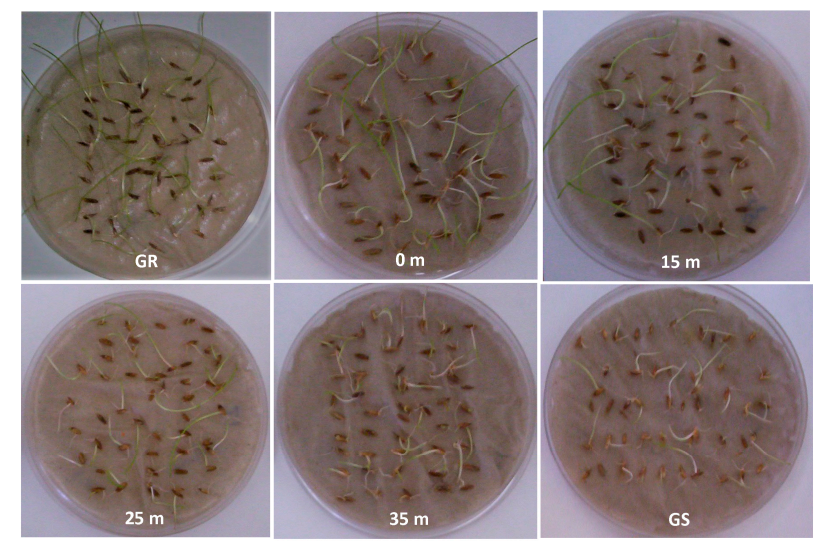

Figure 4. Progenies of pollen receptor plants (spaced from 0 to $35 \mathrm{~m}$ from the glyphosate-resistant plants as the source of pollen), glyphosate-resistant plants (GR, positive control), and isolated glyphosate-susceptible plants (GS, negative control) growing on a glyphosate solution (45 mg ae $\mathrm{L}^{-1}$ ).

The frequency distributions observed for plumule length for each sample were compared to the expected frequency (determined in the negative control), and the null hypothesis $\left(\mathrm{H}_{0}\right)$ was rejected in the cases of progenies obtained $\leq 25 \mathrm{~m}$ from glyphosate-resistant pollen donor plants (Table 1 ). The frequency distribution of plumule length on the progeny of the glyphosate-resistant plants differed significantly from those determined from the progeny of the negative control (Table 1). At least $40 \%$ of individuals from the positive control were found in the three upper classes ( $30-40 \mathrm{~mm}$ to $50-60 \mathrm{~mm}$ ), while less than $2 \%$ of plumules from the negative control were included in these classes (Table 1 , Figure 4).

The progeny of receptor plants growing at $0 \mathrm{~m}$ from the pollen donors showed an increase in individuals with low glyphosate sensitivity compared with the progeny of the negative control. 
Around $13 \%$ of seedlings of these receptor plants showed higher resistance, being categorised in the three upper classes; this represents a seven-fold increase of the frequency found in the negative control (Table 1). Similarly, the comparison of progenies from plants grown at $15 \mathrm{~m}$ from the source of glyphosate resistance showed that the frequencies of upper classes increased by around four-fold (Table 1). Progenies of plants growing at $25 \mathrm{~m}$ from the pollen donor increased, by two-fold, the frequency of the class of 20-30 mm plumule length, compared to the progeny of the negative control (Table 1). Contrasting average values of plumule length, the relative genetic advance to glyphosate resistance, was $81 \%, 27 \%$, and $23 \%$ for the progeny of receptor plants located at 0,15 , and $25 \mathrm{~m}$ from donor plants, respectively. This evidence shows that gene flow occurs from glyphosate-resistant to -susceptible plants located at these distances.

Table 1. Relative frequency (\%) distribution of plumule length in progenies of pollen receptor plants (spaced from 0 to $85 \mathrm{~m}$ from the glyphosate-resistant plants as the source of pollen), glyphosate-resistant plants (GR, positive control), and isolated glyphosate-susceptible plants (GS, negative control). Shaded rows indicate significantly different distributions compared to GS (chi-squared tests, $p<0.05$ ), and frequencies marked by asterisk are significantly different from those recorded in GS ( $z$-test, $p<0.05$ ).

\begin{tabular}{ccccccc}
\hline \multirow{2}{*}{ Progenies } & \multicolumn{7}{c}{ Classes $\mathbf{( m m )}$} \\
\cline { 2 - 7 } & $\mathbf{0 - 1 0}$ & $\mathbf{1 0 - 2 0}$ & $\mathbf{2 0 - 3 0}$ & $\mathbf{3 0 - 4 0}$ & $\mathbf{4 0 - 5 0}$ & $\mathbf{5 0 - 6 0}$ \\
\hline GR & $10.1^{*}$ & $27.0^{*}$ & $22.5^{*}$ & $29.2^{*}$ & $10.1^{*}$ & $1.1^{*}$ \\
$0 \mathrm{~m}$ & $11.1^{*}$ & 47.5 & $28.3^{*}$ & $5.1^{*}$ & $7.1^{*}$ & $1.0^{*}$ \\
$15 \mathrm{~m}$ & $43.9^{*}$ & 35.4 & 12.2 & $6.1^{*}$ & 2.4 & 0.0 \\
$25 \mathrm{~m}$ & $31.6^{*}$ & 48.4 & $16.8^{*}$ & 1.1 & 2.1 & 0.0 \\
$35 \mathrm{~m}$ & 43.0 & 53.2 & 2.5 & 1.3 & 0.0 & 0.0 \\
$45 \mathrm{~m}$ & 53.3 & 41.0 & 4.8 & 1.0 & 0.0 & 0.0 \\
$55 \mathrm{~m}$ & 38.5 & 50.0 & 9.0 & 1.3 & 1.3 & 0.0 \\
$65 \mathrm{~m}$ & 40.4 & 51.1 & 7.4 & 1.1 & 0.0 & 0.0 \\
$75 \mathrm{~m}$ & 39.1 & 50.0 & 8.7 & 2.2 & 0.0 & 0.0 \\
$85 \mathrm{~m}$ & 44.7 & 37.6 & 12.9 & 2.4 & 1.1 & 0.0 \\
GS & 49.1 & 41.8 & 7.3 & 0.9 & 0.9 & 0.0 \\
\hline
\end{tabular}

\subsection{Plant Growth under Glyphosate Treatment}

The progenies differed $(p<0.001)$ in the longitudinal growth of leaves under the glyphosate treatment $\left(1000 \mathrm{~g}\right.$ ae ha $\left.{ }^{-1}\right)$. Thus, in plants obtained from the positive control, growth was around $40 \%$ more than plants obtained from the negative control (Figure 5). The progeny of receptor plants differed $(p<0.05)$ from the positive control, depending on the distance to the glyphosate resistance source where the mother plant was grown (Figure 5).

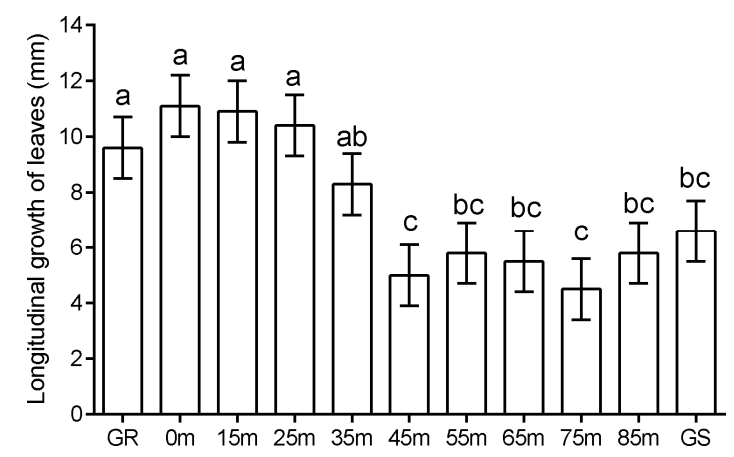

Figure 5. Glyphosate effects on longitudinal growth of leaves of the progeny of pollen receptor plants (spaced from 0 to $85 \mathrm{~m}$ from the glyphosate-resistant plants as the source of pollen), glyphosate-resistant plants (GR, positive control) and isolated glyphosate-susceptible plants (GS, negative control). Bars indicate mean values, error bars represent \pm 1 standard error, and bars with the same letters are not significantly different $(p>0.05$; Tukey's HSD test). 
Progenies of plants located at 0,15 , and $25 \mathrm{~m}$ from donor plants showed a longitudinal growth similar to glyphosate-resistant plants $(p>0.05)$, and these differed from the progeny of isolated susceptible plants (Figure 5). However, plants obtained from receptor plants grown at $35 \mathrm{~m}$ showed an intermediate growth between the progenies of glyphosate-resistant plants and the isolated plants, without differing significantly from either group.

When the distance to the source of glyphosate resistance was $>35 \mathrm{~m}$, the progenies obtained show no significant differences compared to the plants obtained from the negative control. Therefore, at least using this methodology, the main glyphosate-resistant gene flow was detected within $35 \mathrm{~m}$ from the source of resistance.

\subsection{Plant Survival in Response to Glyphosate}

Plant survival was affected by the interaction between the progeny and dose considered $(p<0.001)$. When the recommended dose of glyphosate $\left(1000 \mathrm{~g}\right.$ ae ha $\left.{ }^{-1}\right)$ was applied, herbicide sensitivity of the progeny of plants, located at 0 and $15 \mathrm{~m}$ from the source of pollen, was significantly lower than the susceptible control (Table 2). In these cases, the survival increased by around $15 \%$ compared to the susceptible progeny. At two-fold the recommended dose $\left(2000 \mathrm{~g}_{\mathrm{ae} \mathrm{ha}}{ }^{-1}\right), 100 \%$ of the plants were controlled by the herbicide, regardless of the progeny of receptor plants considered (Table 2). This is in accordance with the inheritance model of glyphosate resistance found, where a dominant gene of incomplete dominance is the base of glyphosate resistance in the studied case. In this sense, plants heterozygous for this gene survive at doses of up to $1000 \mathrm{~g}_{\text {ae }} \mathrm{ha}^{-1}$ [22]. However, when half the recommended dose (500 $\mathrm{g}$ ae ha ${ }^{-1}$ ) was applied, internal variation of sensitivity of receptor plants could mask differences attributable to gene flow from glyphosate-resistant plants (Table 2).

Table 2. Mean percentage of control of the progeny of pollen receptor plants (spaced from 0 to $85 \mathrm{~m}$ from the glyphosate-resistant plants as the source of pollen), glyphosate-resistant plants (GR, positive control) and isolated glyphosate-susceptible plants (GS, negative control) sprayed with glyphosate at 500,1000 , and $2000 \mathrm{~g}$ ae ha ${ }^{-1}$. Means followed by the same letter within columns are not significantly different at $p=0.05$ (Tukey's HSD test).

\begin{tabular}{|c|c|c|c|}
\hline \multirow{2}{*}{ Progenies } & \multicolumn{3}{|c|}{ Control (\%) } \\
\hline & $500 \mathrm{~g}^{\text {ae ha }} \mathrm{h}^{-1}$ & $1000 \mathrm{~g} \mathrm{ae} \mathrm{ha}^{-1}$ & $2000 \mathrm{~g} \mathrm{ae} \mathrm{ha}^{-1}$ \\
\hline GR & $0 \mathrm{a}$ & $47 \mathrm{a}$ & $67 \mathrm{a}$ \\
\hline $0 \mathrm{~m}$ & $34 \mathrm{bc}$ & $84 \mathrm{~b}$ & $100 \mathrm{~b}$ \\
\hline $15 \mathrm{~m}$ & $24 \mathrm{abc}$ & $85 \mathrm{bc}$ & $100 \mathrm{~b}$ \\
\hline $25 \mathrm{~m}$ & $4 \mathrm{ab}$ & $93 \mathrm{~cd}$ & $100 \mathrm{~b}$ \\
\hline $35 \mathrm{~m}$ & $44 \mathrm{c}$ & $100 \mathrm{~d}$ & $100 \mathrm{~b}$ \\
\hline $45 \mathrm{~m}$ & $44 \mathrm{c}$ & $100 \mathrm{~d}$ & $100 \mathrm{~b}$ \\
\hline $55 \mathrm{~m}$ & $47 \mathrm{c}$ & $100 \mathrm{~d}$ & $100 \mathrm{~b}$ \\
\hline $65 \mathrm{~m}$ & $34 \mathrm{bc}$ & $100 \mathrm{~d}$ & $100 \mathrm{~b}$ \\
\hline $75 \mathrm{~m}$ & $37 c$ & $100 \mathrm{~d}$ & $100 \mathrm{~b}$ \\
\hline $85 \mathrm{~m}$ & $40 \mathrm{c}$ & $100 \mathrm{~d}$ & $100 \mathrm{~b}$ \\
\hline GS & $47 \mathrm{c}$ & $100 \mathrm{~d}$ & $100 \mathrm{~b}$ \\
\hline
\end{tabular}

Among the first works of pollen dispersion of Lolium perenne, Griffiths [30] found that the effect of gene flow is highly conditioned by the distance, and a length of $90 \mathrm{~m}$ would be the space that would ensure the isolation of L. perenne populations. Later, Giddings et al. [31] showed, as expected, that pollen deposition declined with distance, but the quantity of pollen grains found between 20 to $80 \mathrm{~m}$ from the source of pollen represented a proportion lower than $10 \%$ of that collected at $0 \mathrm{~m}$. However, these authors suggested that pollen dispersion did not always decrease uniformly with increasing distance from the source, but that it is likely influenced by factors such as wind speed and turbulences [32]. This work was performed using pollen traps that differ from effective gene flow experiments, since the pollen viability and pollen competition of neighbour plants versus the main 
source should be considered $[29,33]$. In the current assay, the pollen of neighbouring susceptible plants would play a role in competition with the pollen of the source of glyphosate resistance, as would be expected in habitual agroecological conditions.

Recently, the gene flow of herbicide-resistant Lolium rigidum was fitted to an exponential decay model at increasing distances. Under field conditions of Spain, the average crossing rate was $8.5 \%( \pm 3.0 \%)$ in plants adjacent to the pollen source, and $2.9 \%( \pm 1.7 \%)$ at $25 \mathrm{~m}$ (farthest distance studied) in the downwind direction [16]. Consistently, the present results indicate that the effective glyphosate-resistant gene flow reached trap plants distanced at $\leq 35 \mathrm{~m}$ from the source of pollen in L. perenne. The analysis of frequency distributions shows that the progeny of these trap plants was enriched, with up to $13.2 \%$ of low glyphosate-sensitive individuals.

Interestingly, Busi et al. [34] have studied the gene flow of herbicide-resistant Lolium rigidum over long distances in Australia. There, pollen-mediated gene flow was detected three kilometres from the fields known to be infested with herbicide-resistant $L$. rigidum as the pollen source. According to the authors, it is presumably that this large source of pollen associated to L. rigidum populations from the Australian wheatbelt greatly contributed to the gene flow at over long distances.

In the current work, when the receptor plants were located at $>35 \mathrm{~m}$, no glyphosate-resistant plants were detected in its progeny by any methodology applied. However, an effective gene flow that contributes to a low frequency of glyphosate-resistant individuals (not possible to detect using the methodology applied here) could be higher compared to the initial frequency of herbicide-resistant plants $\left(10^{-7}\right.$ to $\left.10^{-4}\right)[35,36]$, and it could play an important role in the evolution of glyphosate resistance. Thus, gene flow can increase the frequency of herbicide-resistant individuals in populations without herbicide selection pressure [34].

Therefore, the gene flow would impact at two levels: in regional terms, pollen dispersion would increase the initial frequency of herbicide-resistant individuals, and reduce the time required to reach a high level of resistance. On the other hand, gene flow impacts at the local landscape level, when cross-pollination from an isolated glyphosate-resistant plant to glyphosate-susceptible ones develop patches of resistance that increase year by year. In both cases, seeds and pollen of glyphosate-resistant plants could contribute to the spread of glyphosate resistance, but the pressure of selection through the continuous use of the herbicide is another conditional factor for the process of evolution [8]. Combination of diversified management practices (crop rotations, integration of tactics of weed control, rotations of herbicides with different modes of action, etc.) delays the evolution of herbicide resistance [37]. However, when the pollination period begins, the management of pollen-mediated gene flow is a complicated task [34]. Localised treatments of patches of resistance employing total herbicides [38] or cutting before anthesis, could be considered as methods to reduce or delay pollen production of glyphosate-resistant plants.

\section{Conclusions}

Under field conditions, the effective glyphosate-resistant gene flow was detected within $35 \mathrm{~m}$ from the source of resistance in Lolium perenne; consequently, the hypothesis tested is accepted. The main impact of this evidence would be associated with cross-pollination from glyphosate-resistant plants to glyphosate-susceptible ones, developing patches of resistant plants at the farm level. Management should aim for prevention or delay of flowering of glyphosate-resistant plants, as indicated above. However, only one or a few techniques of control would be ineffective applied in an isolated form. An integrated weed management programme should consider the whole life cycle of the Lolium spp., from emergence to seed production, where pollen-mediated gene flow is a key factor to take into account, at the moment of designing a management strategy. 
Author Contributions: Formal analysis, M.Y., D.G. and A.C.; Funding acquisition, C.I. and A.C.; Investigation, M.Y., C.I., D.G. and A.C.; Resources, M.Y. and C.I.; Supervision, D.G. and A.C.; Writing-original draft, M.Y.

Funding: This research was partially supported by Consejo Nacional de Investigaciones Científicas y Técnicas (CONICET, National Research Council of Argentina-PIP 0165) and the Instituto Nacional de Tecnología Agropecuaria (PRET-BASUR 1272409).

Conflicts of Interest: The authors declare no conflict of interest.

\section{References}

1. Powles, S.; Yu, Q. Evolution in action: Plants resistant to herbicides. Annu. Rev. Plant Biol. 2010, 61, 317-347. [CrossRef] [PubMed]

2. The International Survey of Herbicide Resistant Weeds. Available online: http:/ / www.weedscience.com (accessed on 11 January 2018).

3. Preston, C.; Wakelin, A.; Dolman, F.; Bostamam, Y.; Boutsalis, P. A decade of glyphosate-resistant Lolium around the world: Mechanisms, genes, fitness, and agronomic management. Weed Sci. 2009, 57, 435-441. [CrossRef]

4. Fernández-Moreno, P.; Alcántara de la Cruz, R.; Smeda, R.; De Prado, R. Differential resistance mechanisms to glyphosate result in fitness cost for Lolium perenne and L. multiflorum. Front. Plant Sci. 2017, 8, 1796. [CrossRef] [PubMed]

5. Loureiro, I.; Escorial, C.; Hernández Plaza, E.; González Andújar, J.; Cueca, M. Current status in herbicide resistance in Lolium rigidum in winter cereal fields in Spain: Evolution of resistance 12 years after. Crop Prot. 2017, 102, 10-18. [CrossRef]

6. Kurata, K.; Niinomi, Y.; Shimono, Y.; Miyashita, M.; Tominaga, T. Non-target-site mechanism of glyphosate resistance in Italian ryegrass (Lolium multiflorum). Weed Biol. Manag. 2018, 18, 127-135. [CrossRef]

7. Brunharo, C.; Hanson, B. Multiple herbicide-resistant Italian Ryegrass (Lolium perenne L. spp multiflorum (Lam.)) in California perennial crops: characterization, mechanisms of resistance and chemical management. Weed Sci. 2018, 66, 696-701. [CrossRef]

8. Cousens, R.; Mortimer, M. The evolution of herbicide resistance. In Dynamics of Weed Populations; Cousens, R., Mortimer, M., Eds.; Cambridge University Press: Cambridge, UK, 1995; pp. 243-282.

9. Délye, C.; Jasieniuk, M.; Le Corre, V. Deciphering the evolution of herbicide resistance in weeds. Trends Genet. 2013, 29, 649-658. [CrossRef] [PubMed]

10. Jasieniuk, M.; Brule Babel, A.; Morrison, I. The evolution and genetics of herbicide resistance in weeds. Weed Sci. 1996, 44, 176-193. [CrossRef]

11. Chapman, M.; Burke, J. Letting the gene out of the bottle: The population genetics of genetically modified crops. New Phytol. 2006, 170, 429-443. [CrossRef] [PubMed]

12. Mallory-Smith, C.; Zapiola, M. Gene flow from glyphosate-resistant crops. Pest Manag. Sci. 2008, 64, 428-440. [CrossRef] [PubMed]

13. Busi, R.; Yu, Q.; Barrett-Lennard, R.; Powles, S. Long distance pollen- mediated flow of herbicide resistance genes in Lolium rigidum. Theor. Appl. Genet. 2008, 117, 1281-1290. [CrossRef] [PubMed]

14. Dauer, J.; Mortensen, D.; VanGessel, M. Temporal and spatial dynamics of long-distance Conyza canadensis seed dispersal. J. Appl. Ecol. 2007, 44, 105-114. [CrossRef]

15. Délye, C.; Clément, J.; Pernin, F.; Chauvel, B.; Le Corre, V. Gene flow homogenises the evolution of arable weed populations at the landscape level. Basic Appl. Ecol. 2010, 11, 504-512. [CrossRef]

16. Loureiro, I.; Escorial, M.C.; Chueca, M.C. Pollen-mediated movement of herbicide resistance genes in Lolium rigidum. PLoS ONE 2016, 11, e0157892. [CrossRef] [PubMed]

17. Balfourier, F.; Imbert, C.; Charmet, G. Evidence for phylogeographic structure in Lolium species related to the spread of agriculture in Europe: A cpDNA study. Theor. Appl. Genet. 2000, 101, 131-138. [CrossRef]

18. Manzanares, C. Genetics of Self-Compatibility in Perennial Ryegrass (Lolium perenne L.). Ph.D. Thesis, University of Birmingham, Birmingham, UK, 2013.

19. Devaux, C.; Lavigne, C.; Falentin-Guyomarch, H.; Vautrin, S.; Lecomte, J.; Klein, E.K. High diversity of oilseed rape pollen clouds over an agro-ecosystem indicates long-distance dispersal. Mol. Ecol. 2005, 14, 2269-2280. [CrossRef] [PubMed] 
20. Yanniccari, M.; Istilart, C.; Giménez, D.O.; Castro, A.M. Glyphosate resistance in perennial ryegrass (Lolium perenne L.) from Argentina. Crop Prot. 2012, 32, 12-16. [CrossRef]

21. Yanniccari, M.; Gomez-Lobato, M.; Istilart, C.; Natalucci, C.; Giménez, D.; Castro, A.M. Mechanism of resistance to glyphosate in Lolium perenne from Argentina. Front. Ecol. Evol. 2017, 5, 123. [CrossRef]

22. Yanniccari, M.; Istilart, C.; Giménez, D.O.; Castro, A.M. Inheritance of glyphosate resistance in Lolium perenne and hybrids with Lolium multiflorum. Crop Prot. 2015, 71, 72-78. [CrossRef]

23. Yanniccari, M.; Acciaresi, A. Perennial weeds in Argentinean crop systems: Biological and ecological characteristics and basis for a rational weed management. In Agricultural Research Updates; Gorawala, P., Mandhatri, S., Eds.; Nova Science Publishers: New York, NY, USA, 2013; Volume 5, pp. 43-62.

24. Istilart, C.; Yanniccari, M. Análisis de la evolución de malezas en cereals de invierno durante 27 años en la zona sur de la pampa húmeda argentina. Malezas Probl. Aapresid 2012, 113-116.

25. Scursoni, J.; Gigón, R.; Martín, A.; Vigna, M.; Leguizamón, E.; López, R. Changes in weed communities of spring wheat crops of Buenos Aires province of Argentina. Weed Sci. 2014, 62, 51-65. [CrossRef]

26. Vigna, M.; Gigón, R.; Yanniccari, M.; Istilart, C.; Pizarro, M. Evaluación Preliminar del Estado de la Resistencia en Lolium spp. y Avena fatua en el SO de Buenos Aires, Argentina. In Proceedings of the XXIII Congreso Latinoamericano de Malezas-III Congreso Iberoamericano de Malezas, La Habana, Cuba, 26-30 June 2017.

27. Streibig, J.; Rudemo, M.; Jensen, J. Dose-response curves and statistical models. In Herbicide Bioassays; Streibig, J., Kudsk, P., Eds.; CRC Press: Boca Raton, FL, USA, 1993; pp. $29-55$.

28. Yanniccari, M.; Istilart, C.; Giménez, D.O.; Acciaresi, H.; Castro, A.M. Efecto del glifosato sobre el crecimiento y acumulación de azúcares libres en dos biotipos de Lolium perenne de distinta sensibilidad al herbicida. Planta Dan. 2012, 30, 155-164. [CrossRef]

29. Dafni, A.; Firmagi, D. Pollen viability and longevity: Practical, ecological and evolutionary implications. Plant Syst. Evol. 2000, 222, 113-132. [CrossRef]

30. Griffiths, D. The liability of seed crops of perennial ryegrass (Lolium perenne) to contamination by wind-borne pollen. J. Agric. Sci. 1950, 40, 19-38. [CrossRef]

31. Giddings, G.; Sackville-Hamilton, N.; Hayward, M. The release of genetically modified grasses. Part 1: Pollen dispersal to traps in Lolium perenne. Theor. Appl. Genet. 1997, 94, 1000-1006. [CrossRef]

32. Giddings, G.; Sackville-Hamilton, N.; Hayward, M. The release of genetically modified grasses. Part 2: The influence of wind direction on pollen dispersal. Theor. Appl. Genet. 1997, 94, 1007-1014. [CrossRef]

33. Rognli, O.; Nilsson, N.; Nurminiemi, M. Effects of distance and pollen competition on gene flow in the wind-pollinated grass Festuca pratensis Huds. Heredity 2000, 85, 550-560. [CrossRef] [PubMed]

34. Busi, R.; Michel, S.; Powles, S.; Délye, C. Gene flow increases the initial frequency of herbicide resistance alleles in unselected Lolium rigidum populations. Agric. Ecosyst. Environ. 2011, 142, 403-409. [CrossRef]

35. Neve, P.; Diggle, A.J.; Smith, F.P.; Powles, S.B. Simulating evolution of glyphosate resistance in Lolium rigidum I: Population biology of a rare resistance trait. Weed Res. 2003, 43, 404-417. [CrossRef]

36. Preston, C.; Powles, S. Evolution of herbicide resistance in weeds: Initial frequency of target site-based resistance to acetolactate synthase-inhibiting herbicides in Lolium rigidum. Heredity 2002, 88, 8-13. [CrossRef] [PubMed]

37. Chauhan, B.S.; Gill, G.S. Ecologically based weed management strategies. In Recent Advances in Weed Management; Chauhan, B.S., Mahajan, G., Eds.; Springer: New York, NY, USA, 2014; pp. 1-11.

38. Steadman, K.J.; Eaton, D.M.; Plummer, J.; Ferris, D.G.; Powles, S. Late-season non-selective herbicide application reduces Lolium rigidum seed numbers, seed viability, and seedling fitness. Aust. J. Agric. Res. 2006, 57, 133-141. [CrossRef]

(C) 2018 by the authors. Licensee MDPI, Basel, Switzerland. This article is an open access article distributed under the terms and conditions of the Creative Commons Attribution (CC BY) license (http://creativecommons.org/licenses/by/4.0/). 